\title{
WATER TRANSPORT STUDY IN HIGH TEMPERATURE PROTON EXCHANGE MEMBRANE FUEL CELL STACK
}

\author{
Dario Bezmalinović ${ }^{1,2, *}$, Stephan Strahl $^{2}$, Vicente Roda ${ }^{2}$, Attila Husar ${ }^{2}$ \\ ${ }^{1}$ Faculty of Electrical Engineering, Mechanical Engineering and Naval Architecture, \\ University of Split, Ruđera Boškovića 32, 21000 Split, Croatia \\ ${ }^{2}$ Institut de Robòtica i Informàtica Industrial, CSIC-UPC, Parc Tecnològic de Barcelona. \\ C/ Llorens i Artigas 4-6, 08028 Barcelona, Spain
}

\begin{abstract}
A study of water transport in a high temperature phosphoric acid doped polybenzimidazole (PBI) membrane fuel cell stack is reported. Tests with different stoichiometries of dry cathode and different humidity levels of anode are performed. It is found that water transport across the membrane electrode assembly (MEA) is noteworthy and that water vapor partial pressure on the anode outlet is almost always higher than on the cathode outlet, even when using dry hydrogen. The water transport is a strong function of current density but it also depends on stoichiometry and humidity level. In a series of tests with dry nitrogen on one side and humid nitrogen on the other side, the membrane's water permeability coefficient is determined to be $2.4 \times 10^{-13} \mathrm{~mol} \mathrm{~s}^{-1} \mathrm{~cm}^{-1} \mathrm{~Pa}^{-1}$ at $160{ }^{\circ} \mathrm{C}$ which is more than an order of magnitude higher than the values previously reported in the literature. Also, the results indicate that the permeability coefficient might be relative humidity dependent and could even be somewhat higher than the value reported here, but further investigation is needed. The experimental findings are reproduced and explained with a 2D steady state computational fluid dynamics (CFD) model. Internal water transport profiles across the membrane and along the gas flow channels are presented and discussed.
\end{abstract}

\section{Keywords:}

HTPEM; PBI; water transport; humidification; modeling

\section{Introduction}

High temperature polymer electrolyte membrane (HTPEM) fuel cells are generally considered as the next generation of PEM fuel cells because of several advantages due to elevated operating temperatures: (i) better kinetics, (ii) simplified cooling and water management, (iii) higher amount of recoverable heat and most importantly (iv) higher tolerance to fuel contamination (especially CO) [1,2]. The last two points are especially interesting for combined heat and power systems with integrated fuel processors $[3,4]$. Great efforts have been made to develop proton conducting membranes at temperatures higher than $100{ }^{\circ} \mathrm{C}$ and among many candidates phosphoric acid $\left(\mathrm{H}_{3} \mathrm{PO}_{4}\right)$ doped polybenzimidazole $(\mathrm{PBI})$ membranes emerged as the most interesting [2]. PBI is a family of amorphous thermoplastic

\footnotetext{
${ }^{*}$ Corresponding author. E-mail address: dbezma@,fesb.hr, telephone number: +38521305947 , fax: $+38521463877$
} 
polymers with excellent chemical and mechanical properties. Doped with phosphoric acid, PBI becomes a very good proton conductor [5]. Extensive research has been done on $\mathrm{PBI}-\mathrm{H}_{3} \mathrm{PO}_{4}$ membranes in recent years. The literature indicates that with various doping levels of phosphoric acid the membranes exhibit high proton conductivity, similar or even higher than Nafion ${ }^{\circledR}$ based membranes [5-9]. They can tolerate up to $10,000 \mathrm{ppm}$ of $\mathrm{CO}$ at $150{ }^{\circ} \mathrm{C}$ [10] and have a lifetime of over 20,000 hours at $160{ }^{\circ} \mathrm{C}$ [11]. Normally these membranes operate between 120 and $180{ }^{\circ} \mathrm{C}$ and the performance rises with temperature although at the expense of durability [5,9]. One of the biggest drawbacks associated with $\mathrm{PBI}_{-} \mathrm{H}_{3} \mathrm{PO}_{4}$ based HTPEM fuel cells is a high activation overpotential due to low electrochemically active surface area of the platinum catalyst. This is because of two phenomena: strong adsorption of phosphate anions onto the catalyst and agglomeration of Pt particles which is more significant in the early stages of the membrane's life [12]. Moreover, since carbon corrosion is a strong function of potential and temperature it may have disastrous consequences near open circuit voltages in HTPEM fuel cells [13]. Thus, start-up and shut-down procedures are extremely important [14].

One of the major advantages of phosphoric acid doped PBI membranes is that the reactant gases do not need to be humidified. Therefore, most of the research on $\mathrm{PBI}-\mathrm{H}_{3} \mathrm{PO}_{4}$ membranes is done with dry reactants. However, in real world applications it is almost impossible to supply dry reactants. Ambient air is always humid plus HTPEM are usually meant to run on the on-site produced reformate gas which can contain large amounts of water vapor [15]. Furthermore, working in a dead-end mode with pure hydrogen in order to reduce fuel consumption requires periodical purges due to dilution of the hydrogen on the anode side. Dilution is caused by the permeation of nitrogen and water molecules from the cathode. With nitrogen permeation through the membrane reportedly being very low [16], water build-up on the anode could be the main reason behind the necessity of a purge. It is therefore important to investigate the effects of water vapor on the cell's performance.

Proton conduction mechanism in the $\mathrm{PBI}-\mathrm{H}_{3} \mathrm{PO}_{4}$ membranes is not water assisted, in other words a proton does not need an $\mathrm{H}_{2} \mathrm{O}$ molecule to migrate from anode to cathode in form of a hydronium ion (vehicle mechanism). It is primarily structure diffusion where proton migration occurs between hydrogen bonds (Grotthuss mechanism) [2]. However, water still plays an important role in the reaction mechanisms. The presence of water ionizes phosphoric acid and increases proton activity what in turn enhances oxygen reduction reaction [17]:

$$
\mathrm{H}_{3} \mathrm{PO}_{4}+\mathrm{H}_{2} \mathrm{O} \leftrightarrow \mathrm{H}_{3} \mathrm{O}^{+}+\mathrm{H}_{2} \mathrm{PO}_{4}^{-} \quad(1)
$$

Furthermore, solubility of oxygen in water is much higher than in $\mathrm{H}_{3} \mathrm{PO}_{4}$. Therefore, with higher water content in the electrolyte the oxygen concentration in the catalyst layer increases and at the same time oxygen diffusion is improved due to decreased viscosity of the electrolyte [17]. Phosphoric acid is also known to dehydrate at temperatures higher than $120{ }^{\circ} \mathrm{C}$ forming less conductive pyrophosphoric acid [18,19]:

$$
2 \mathrm{H}_{3} \mathrm{PO}_{4} \leftrightarrow \mathrm{H}_{4} \mathrm{P}_{2} \mathrm{O}_{7}+\mathrm{H}_{2} \mathrm{O} \quad(2)
$$

The previous reaction is fully reversible but the equilibrium constant of the reaction is temperature and relative humidity dependent [16]. At higher temperatures, higher relative humidity is needed in order to reverse the reaction. It is generally believed that 
electrochemically produced water within the cell is enough to stop the abovementioned process. However, the authors of reference [20] reported a significant drop in the cell performance over time at an operating temperature of $175{ }^{\circ} \mathrm{C}$ which was attributed to phosphoric acid dehydration. The same trend was noticed at $150{ }^{\circ} \mathrm{C}$ but at a slower rate. Another group [21] reported the same phenomenon but the decline in performance was reversed once the anode stream was humidified at 1\% RH. Several groups of authors have shown that the cell's ohmic resistance decreases with humidification of one or both reactants [8,22-26]. Authors in [23] reported performance improvement using a humidified hydrogen stream over the entire range of current densities for the ABPBI membrane at $190{ }^{\circ} \mathrm{C}$. The same was reported in [24] for the in-house built membrane electrode assembly (MEA) between $120-160{ }^{\circ} \mathrm{C}$. Other authors [8,25] found that the influence on the overall performance is negligible and can even be negative at higher water partial pressures due to reactant dilution.

From this literature review it is clear that the water, which is always going to be present, influences the way the HTPEM fuel cell works and it is the opinion of the authors of this paper that investigating water transport in the MEA is of relevant interest. Data on the water transport within the $\mathrm{PBI}-\mathrm{H}_{3} \mathrm{PO}_{4}$ membranes and MEA's is very scarce in the literature and to the best of our knowledge there is only one group of authors that has so far quantified this phenomenon [8].

In the first part of the paper experimental results are presented. Effects of cathode stoichiometry and anode humidification on water transport in operational stack are discussed. Also, a water transport coefficient for the different operating temperatures and humidity levels is calculated. In the second part of the paper, a 2D steady state computational fluid dynamics (CFD) fuel cell model is presented in order to investigate the local water transport across the MEA. The model is validated against the experimental results.

\section{Experimental analysis}

\subsection{Experimental setup}

The system under study in this work is the commercially available 12 cell HTPEM fuel cell stack from ZBT [27] with a nominal power output of $120 \mathrm{~W}_{\mathrm{el}}$. The active area of the individual cells is $50 \mathrm{~cm}^{2}$ equipped with Celtec ${ }^{\circledR}-\mathrm{P} 1000$ MEAs manufactured by BASF which consist of anode and cathode gas diffusion layers (GDL) and catalyst layers [28]. The fuel cell stack is installed in an insulated box with an integrated heater and a recirculation cooling fan to maintain uniform fuel cell stack temperature. The anode and cathode reactants are pure hydrogen and synthetic air, respectively. The reactant gases are connected to the fuel cell stack in a co-flow "U" configuration. Each reactant subsystem at the inlet contains a Bronkhorst EL-FLOW ${ }^{\circledR}$ mass flow controller (accuracy $\pm 0.5 \%$ of reading plus $\pm 0.1 \%$ of full scale) and CellKraft P-10 membrane-based humidifier with a dew point sensor for control. The inlet lines are configured so that the gases can be supplied either humidified or dry through bypass valves. An additional (bypass) valve is placed in each line after the humidifier to prevent the stack from being in contact with the humidifiers after performing a shutdown purge with dry gases. The inlet and outlet lines are heated with temperature controlled line heaters in order to prevent condensation. Absolute pressures of the reactants at the inlet are measured with Keller PR 23 absolute piezoresistive pressure transmitters, while the pressure drops of each reactant through the stack are measured with Keller PD 23 differential pressure transmitters (accuracy $\pm 0.2 \%$ of full scale for the both). Dew points of the outlet (exhaust) gases are monitored with Vaisala HMM 211 dew point sensors (accuracy $\pm 2 \% \mathrm{RH}$ ) placed 
right at the outlet of the stack. Both dew point sensors were calibrated prior to the experiments in accordance with manufacturer's recommendation. The fuel cell temperature is measured at three points in the stack, one in each exterior cell and one in the middle of the stack. The fuel cell test station schematic is shown in Fig. 1. LabVIEW data acquisition software was used in conjunction with the National Instruments Analog Input Module for Fuel Cells NI-9206 to measure the stack and single cell voltages. The stack current is measured with a Chauvin Arnoux E3N current clamp.

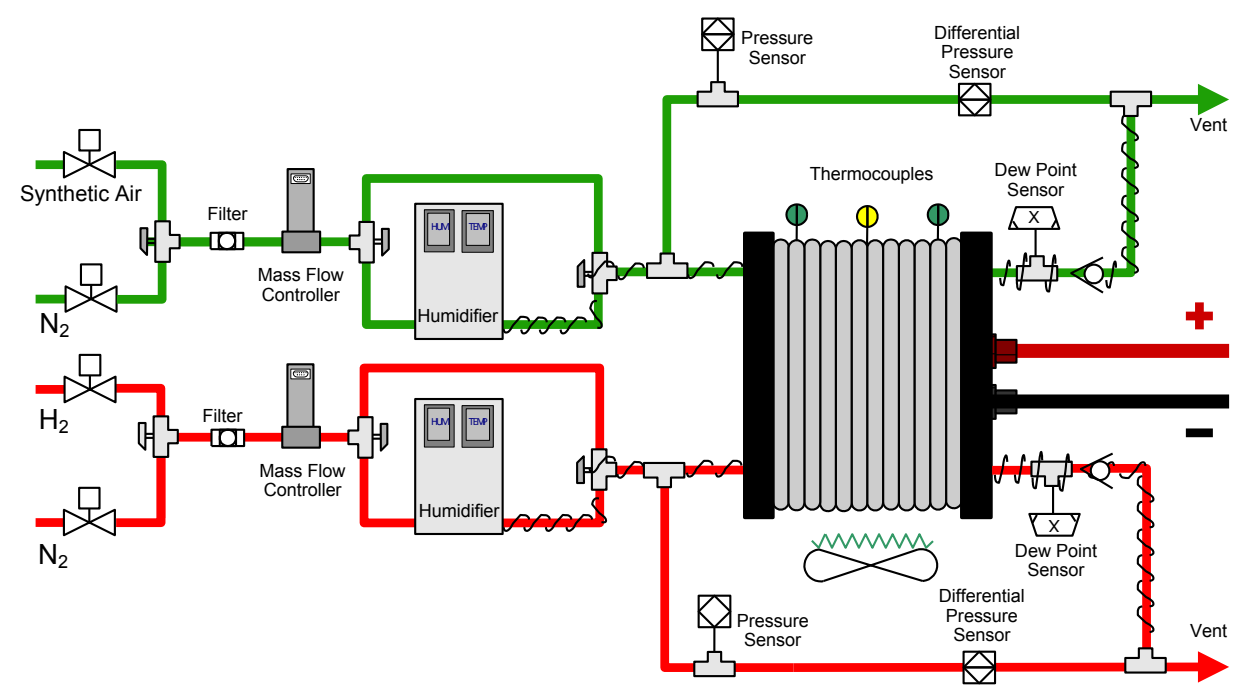

Fig. 1. Experimental test station schematic.

\subsection{Water transport during operation}

In this set of experiments water transport across the MEA of the working stack has been quantified. The only mechanism assumed here to drive water vapor molecules across the MEA is the water vapor partial pressure gradient across the MEA as electro-osmotic drag (EOD) is reported to be virtually zero for PBI- $\mathrm{H}_{3} \mathrm{PO}_{4}$ membranes [29,30]. Water transport $\dot{Q}\left(\mathrm{~mol} \mathrm{~s}^{-1} \mathrm{~cm}^{-2}\right)$, is defined here as the difference of the water vapor molar flows between anode outlet and anode inlet divided by the number of cells in the stack and active area of the cell. For the dry reactants the only water present in the system is the water being generated at the cathode. Some amount of this water crosses the membrane and in this case water flow at the anode outlet equals water transport since the anode inlet was dry. In the case of humidified anode stream, anode outlet water vapor flow can in some cases be lower than at the inlet, i.e. water net transport was from anode to cathode (negative water transport). To determine water transport, dew points of the outlet streams of both, anode and cathode were recorded as well as the absolute pressures at both outlets. Knowledge of the stream's dew point gives water partial pressure and thus water vapor flow at the outlet can be calculated by

$$
\dot{N}_{w, a n, o}=\dot{N}_{H 2, a n, o} \frac{p_{p, w}}{p_{a b s, o}-p_{p, w}}\left[\mathrm{~mol} \mathrm{~s}^{-1} \mathrm{~cm}^{-2}\right]
$$

where $\dot{N}_{w, a n, o}$ and $\dot{N}_{H 2, a n, o}$ are water vapor and hydrogen molar flows at the stack's anode outlet respectively, while $p_{p, w}$ and $p_{a b s, o}$ are water vapor partial pressure and absolute pressure at the stack's anode outlet, respectively. The same was done at the cathode side for the water balance calculation to confirm reliability of the results. 
Experiments were conducted at seven current densities ranging from 0.1 to $0.7 \mathrm{Acm}^{-2}$ with a step of $0.1 \mathrm{Acm}^{-2}$ at the average stack temperature of $160{ }^{\circ} \mathrm{C}$. At current densities higher than $0.7 \mathrm{Acm}^{-2}$ the stack temperature could not be maintained. As the oxidant, dry synthetic air was always used, while as a fuel, pure hydrogen was used, both dry and humidified. Stoichiometry of hydrogen flow was 1.3 for each experiment while air stoichiometry was varied between 3,2 and 1.5. Prior to the start of each experiment, the stack was left running for an hour at $0.1 \mathrm{Acm}^{-2}$ with operating conditions of respective experiment to allow the membrane electrolyte to reach equilibrium with the gas streams. The stack was kept for 20 minutes at each current density to make sure steady state conditions are reached. The average reading of the last 30 seconds (one point per second data logging) was taken for the analysis. Each experiment was conducted twice, first in the descending (increasing current) and then in the ascending (decreasing current) direction, in order to ensure repeatability of the readings. The experiment was shown to be repeatable with negligible hysteresis (deviation $<1 \%$ ).

In Fig. 2 water transport for different air stoichiometries in a dry hydrogen mode are shown. Water transport across the MEA increases slightly progressively with current density, while expectedly, decreases with the increase of the cathode stoichiometry due to lower partial pressure of water on the cathode side at higher air flows. These findings are similar to those reported in [8], although it seems that in this study water transport is somewhat lower. However, it should be noted that the authors in [8] used Celtec ${ }^{\circledR}$ P 2100 MEAs in their experiments.

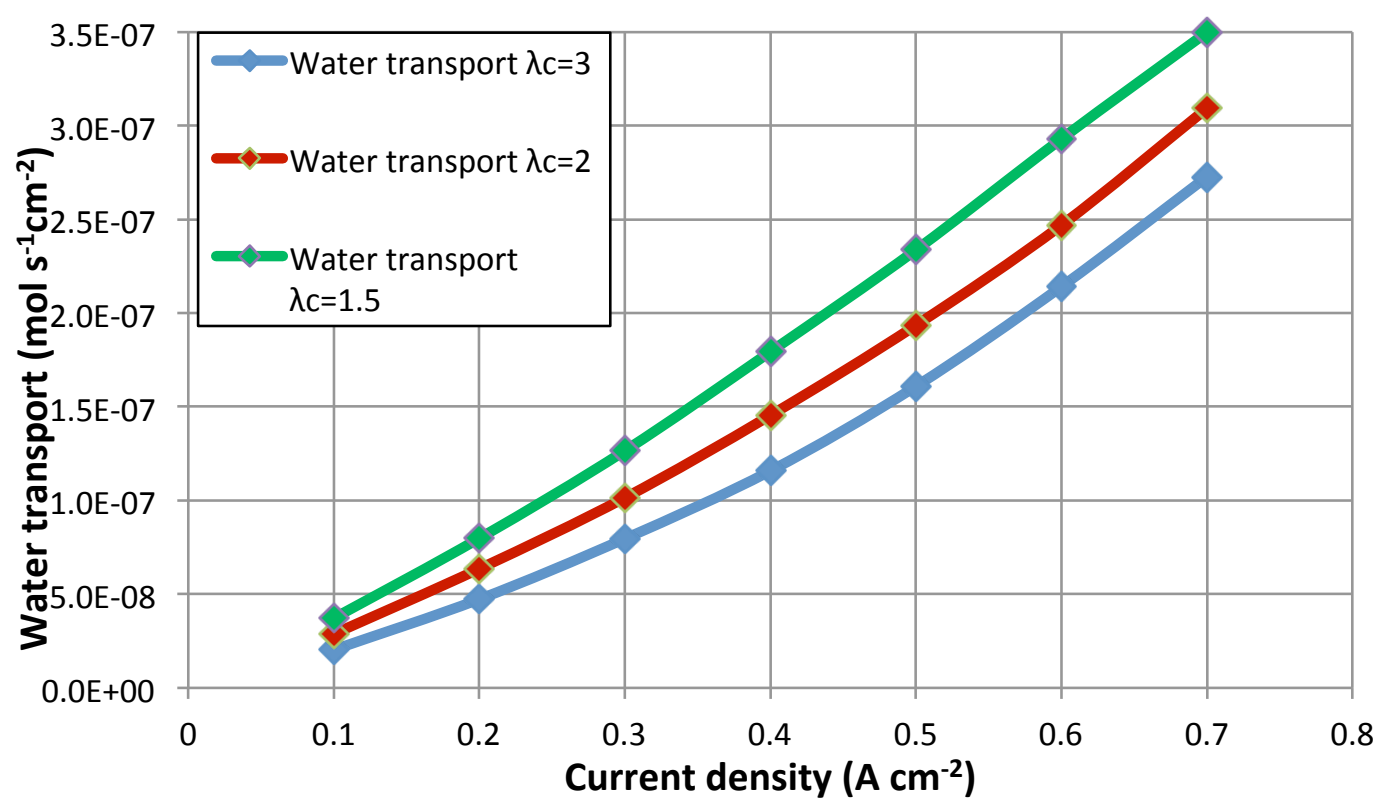

Fig. 2. Water transport for different air stoichiometries and dry hydrogen flow.

Fig. 3 shows the outlet water vapor partial pressure of anode and cathode streams for different cathode stoichiometries. Surprisingly, water vapor partial pressure is almost always higher at the anode outlet, except at low current densities, despite not humidifying the anode stream. These results indicate that at some point along the channel length local water transport changes direction and goes from anode to cathode. Authors in [8] reported similar behavior although in their study, water partial pressure at the anode outlet was higher at all current 
densities. However, as mentioned previously, it seems that in this study, water transport occurs at somewhat lower rate.

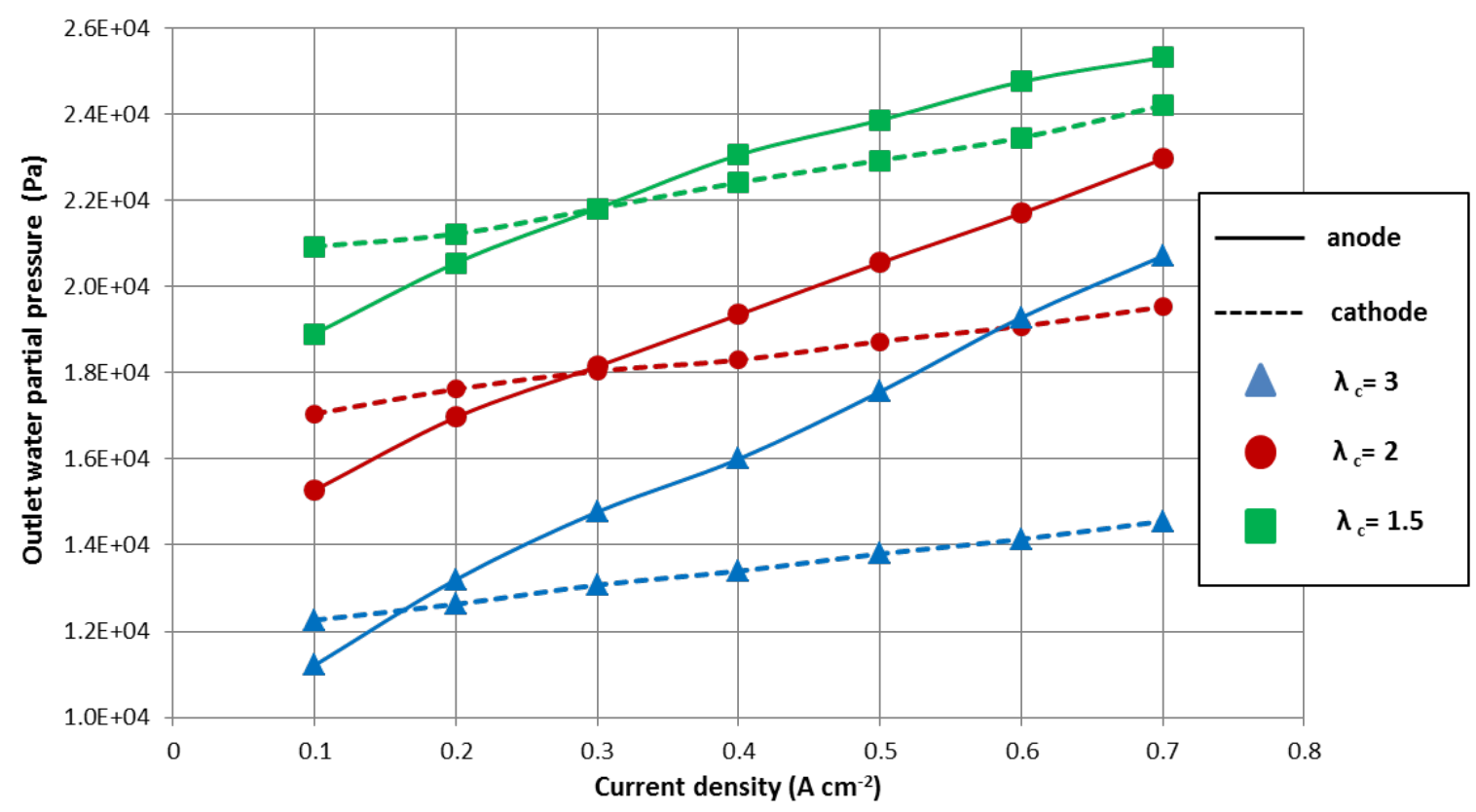

Fig. 3. Water vapor partial pressures at the anode and cathode outlets for different cathode stoichiometries.

Fig. 4 shows the water transport for humidified hydrogen at two different dew points, 33 and $45{ }^{\circ} \mathrm{C}$ for the cathode stoichiometry of 2 . Even though the hydrogen inlet flow contains some water vapor, unlike air flow, the overall water transport is still almost always positive (from cathode to anode) for $33^{\circ} \mathrm{C}$ dew point humidification and rises with the current. For the $45{ }^{\circ} \mathrm{C}$ dew point humidification however, water transport is always negative and its magnitude tends to rise with current. Still, this rise is regressive and at some point water transport from anode to cathode starts to decrease.

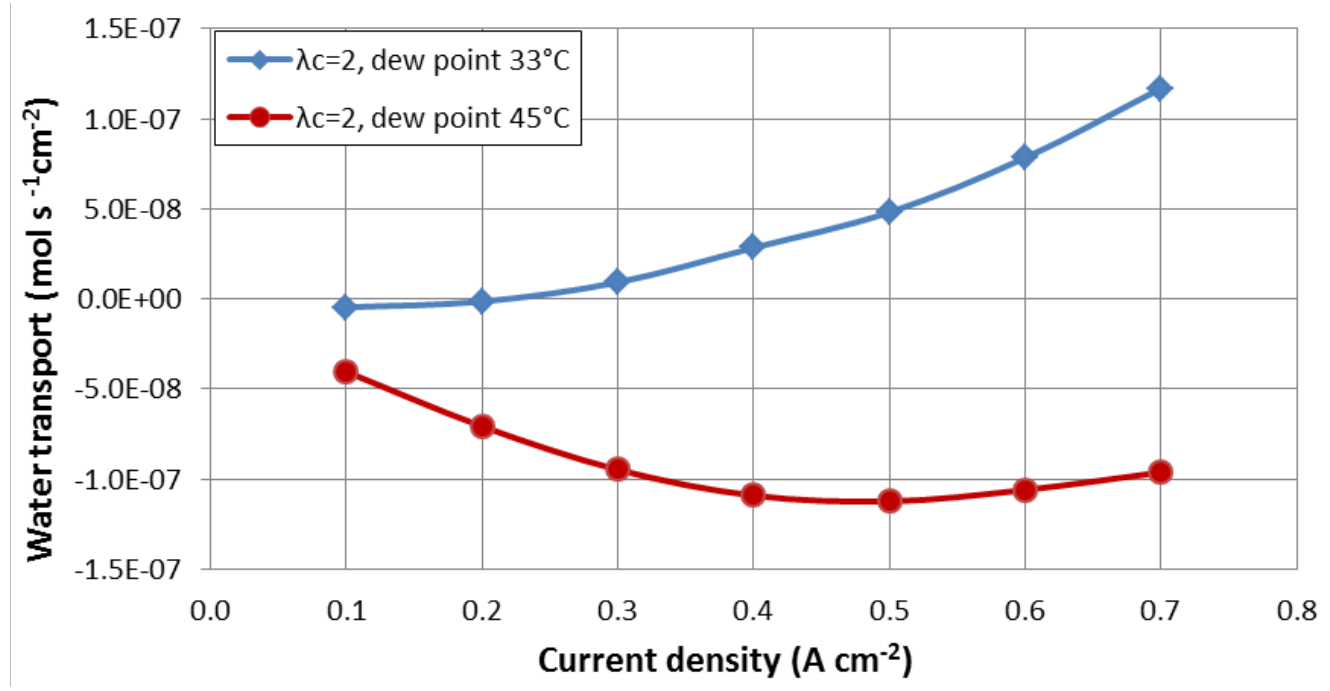

Fig. 4. Water transport at different anode dew point humidification. 


\subsection{Water transport coefficient}

To determine the water transport coefficient both sides of the stack were supplied with a nitrogen stream, dry on the one side and humid on the other, similar as presented in [31] and [32]. From dew point measurements at the outlets of the stack, total water transport across the MEA and water partial pressures at the outlets are calculated. Water partial pressure on the humidified side decreases along the channel length while it increases on the dry side. Knowledge of the water partial pressures at both inlets and outlets are used to determine the logarithmic mean pressure difference (LMPD) across the membrane [31], using the same analogy to temperatures in a heat exchanger, as defined in equation (5). The water transport coefficient, $k$, can be calculated by

$$
k=\frac{\dot{Q}}{\Delta p_{L M P D}}\left[\mathrm{~mol} \mathrm{~s}^{-1} \mathrm{~cm}^{-2} \mathrm{~Pa}^{-1}\right]
$$

where $\dot{Q}$ is total water transport $\left(\mathrm{mol} \mathrm{s}^{-1} \mathrm{~cm}^{-2}\right)$ and $\Delta p_{L M P D}$ is logarithmic water pressure difference which can be calculated by

$$
\Delta p_{L M P D}=\frac{\Delta p_{\text {in }}-\Delta p_{\text {out }}}{\ln \left(\frac{\Delta p_{\text {in }}}{\Delta p_{\text {out }}}\right)}[\mathrm{Pa}]
$$

where $\Delta p_{\text {in }}$ and $\Delta p_{\text {out }}$ are water partial pressure differences at the inlet and the outlet of the stack, Fig. 5. To maximize calculation accuracy, water partial pressures on both sides should not change significantly along the channel length. This can be accomplished by using high flows of nitrogen and high humidity in the humidified stream.

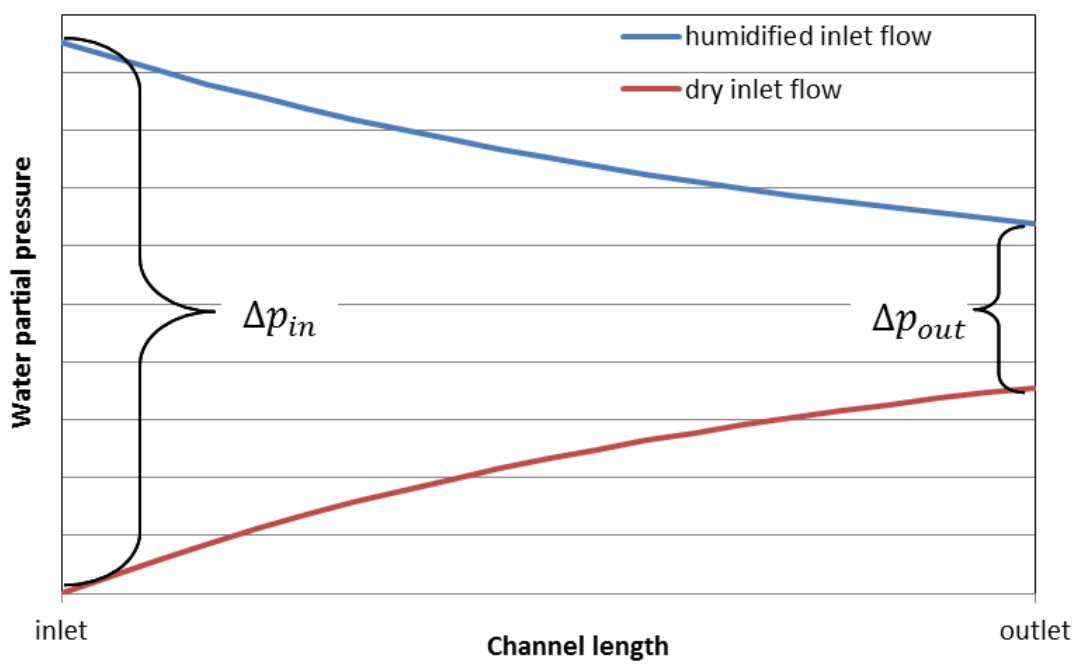

Fig. 5. Water partial pressures differences along the channel length. 
Several experiments were conducted at four different set points, namely two different relative humidity levels of the humid inlet gas at two different stack temperatures. Tested operating temperatures of the stack were $140{ }^{\circ} \mathrm{C}$ and $160{ }^{\circ} \mathrm{C}$. At each operating temperature several tests were done with humidified gas streams at two different dew points, $\sim 32{ }^{\circ} \mathrm{C}$ and $\sim 50{ }^{\circ} \mathrm{C}$ which correspond to water partial pressures of $\sim 4.7$ and $\sim 12 \mathrm{kPa}$, respectively. These dew points were chosen because according to [16] water partial pressure equilibriums for the dimerization of the $85 \mathrm{wt} . \%$ phosphoric acid in the PBI are 5.4 and $10 \mathrm{kPa}$ at the 150 and $170{ }^{\circ} \mathrm{C}$, respectively. All tests at the aforementioned set points were completed with cathode stream humidified first. The same tests were repeated later, only this time with the anode stream humidified. It should be noted though, that relative humidities of the anode inlet streams were somewhat lower than the ones with the humidified cathode due to difficulties with control of the anode side humidifier. Nitrogen flow rates were kept the same on both sides to ensure approximately equal gas velocities and pressure drops throughout the stack. Thus, water crosses the MEA only due to partial pressure differences as the absolute pressures were the same on both sides. As mentioned, high flow rates of nitrogen were required to maintain reasonably high outlet water partial pressure difference between the anode and cathode streams. At each set point at least two tests were done with different nitrogen flow rates for the humidification of each stream, between 5 and 10 standard liters per minute (SLPM) at $140{ }^{\circ} \mathrm{C}$ and between 5 and 7 SLPM at $160{ }^{\circ} \mathrm{C}$. Generally, flow rates of 10 SLPM should be considered more reliable for the calculation; however at $160{ }^{\circ} \mathrm{C}$ it was not possible to maintain stack temperature for flows higher than 7 SLPM due to excessive heat removal by the nitrogen gas. Each test at the same set point was recorded for at least 20 minutes to ensure steady state conditions. Whenever the set point was changed (change of the stack temperature or humidification dew point), the flow was left running through the stack for at least one hour before resuming the tests to allow the membrane electrolyte to reach equilibrium with the gas streams.

Altogether 20 measurements were made and the calculated coefficients for each of them are shown in Fig. 6. The results are fairly consistent and some conclusions can be drawn. First, different nitrogen flow rates at the same set points exhibit very similar results which indicate that the results obtained with lower flow rates are reliable. Also, it seems that there is no difference between water transport coefficients in either direction. It appears that the water transport coefficient is slightly higher at a stack temperature of $140{ }^{\circ} \mathrm{C}$ with a calculated average value of $5.76 \times 10^{-11} \mathrm{~mol} \mathrm{~s}^{-1} \mathrm{~cm}^{-2} \mathrm{~Pa}^{-1}$ versus $4.56 \times 10^{-11} \mathrm{~mol} \mathrm{~s}^{-1} \mathrm{~cm}^{-2} \mathrm{~Pa}^{-1}$ at $160{ }^{\circ} \mathrm{C}$. This may be attributed to higher water content in the electrolyte at lower temperatures for the same water vapor partial pressures due to water solubility in phosphoric acid [16]. At $160{ }^{\circ} \mathrm{C}$ the calculated coefficient is constant regardless of the wet gas inlet humidity. At $140{ }^{\circ} \mathrm{C}$ the coefficient seems to increase slightly with the humidification of the cathode stream while the same cannot be said for the anode stream humidification due to the inability to humidify it at higher dew points. Further examination should be made at even higher dew points to clarify whether this is a trend or experimental uncertainty. This could imply that the relative humidity slightly enhances water transport across the MEA; however, the obtained differences are so small that such a claim would be too strong without further investigation. 
a)

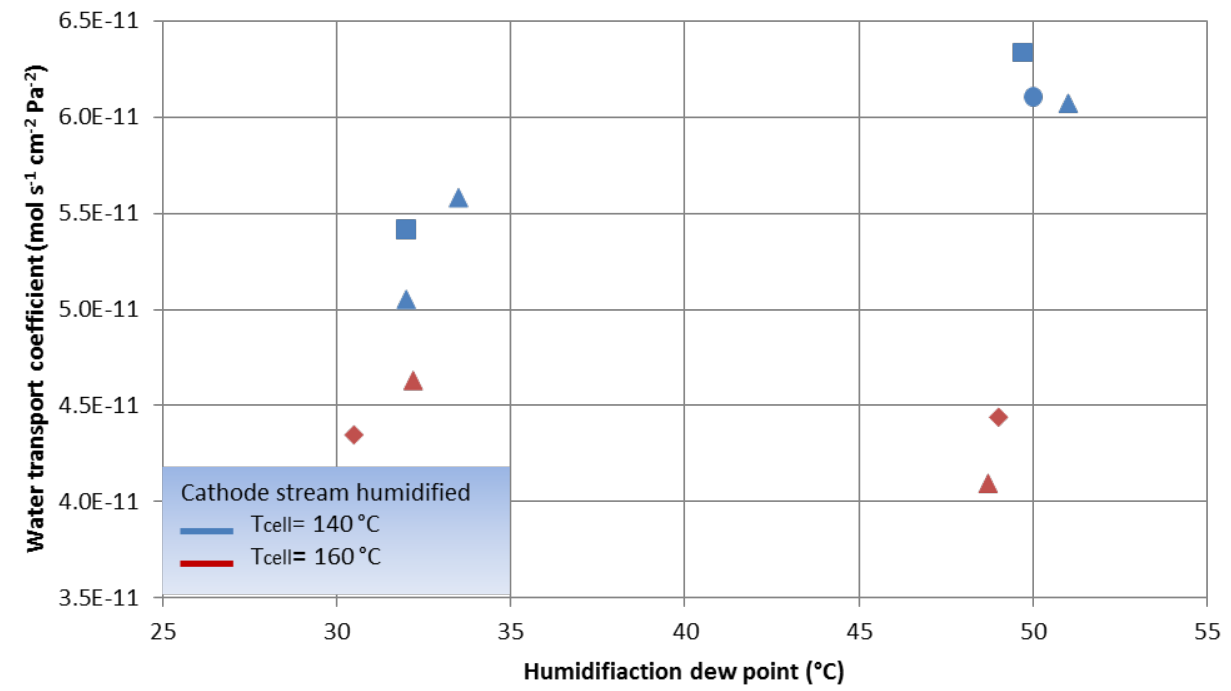

b)

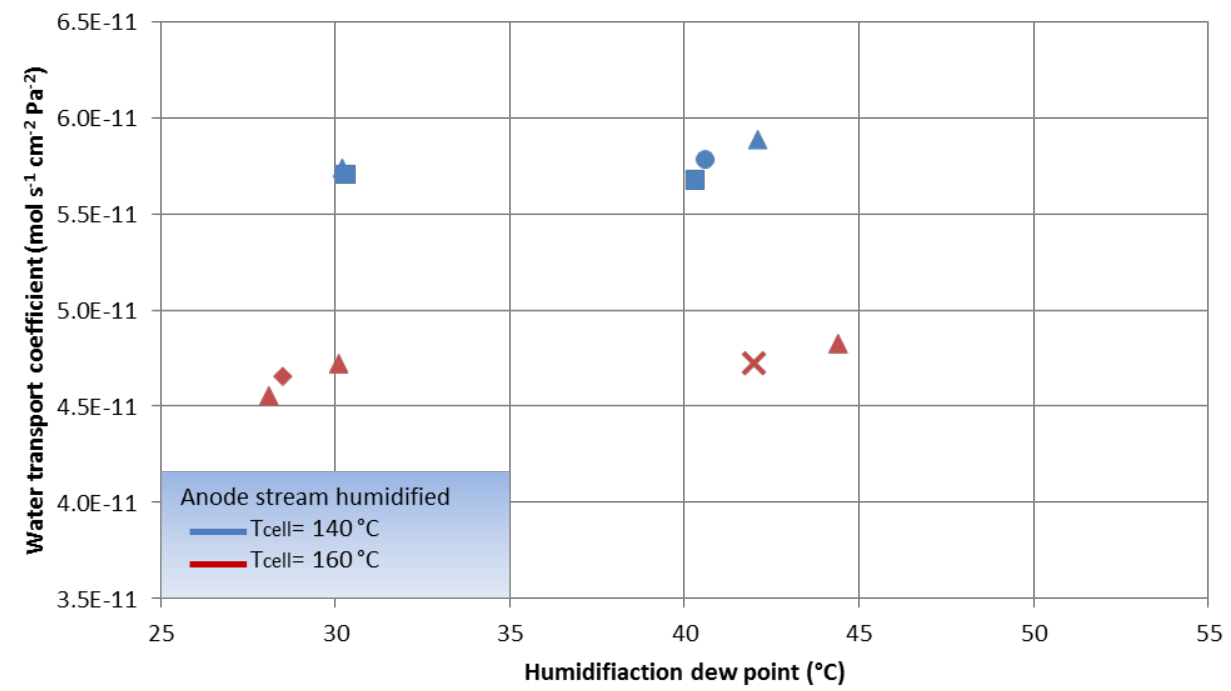

Fig. 6. Water transport coefficient obtained at different stack temperatures for different dew points of the a) cathode inlet stream and b) anode inlet stream. Blue markers indicate coefficient obtained at $140{ }^{\circ} \mathrm{C}$ while red markers indicate coefficient obtained at $160{ }^{\circ} \mathrm{C}$.

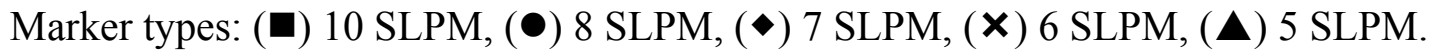

In order to extract the membrane water transport coefficient from the obtained value for the whole MEA, the contribution of both GDLs should be deducted. If $k$ is the water transport coefficient through the MEA, then the water transport resistance through the MEA is $1 / k$. It is the sum of the membrane, anode and cathode GDLs water transport resistances:

$$
\frac{1}{k}=\frac{1}{k_{G D L, a}}+\frac{1}{k_{m}}+\frac{1}{k_{G D L, c}}\left[\mathrm{~Pa} \mathrm{~s} \mathrm{~cm}^{2} \mathrm{~mol}^{-1}\right]
$$

The water transport coefficient through the cathode GDL can be calculated by 


$$
k_{G D L, c}=\frac{D_{H_{2} O}^{e f f}}{R T \delta_{G D L}}\left[\mathrm{~mol} \mathrm{~s}^{-1} \mathrm{~cm}^{-2} \mathrm{~Pa}^{-1}\right]
$$

where $R, T, \delta_{G D L}$ and $\boldsymbol{D}_{\mathbf{H}_{\mathbf{2}} \boldsymbol{O}}^{\text {eff }}$ are universal gas constant, temperature, GDL's thickness and effective water diffusivity through air in the GDL, respectively. GDL's thickness in a working Celtec $^{\circledR}-\mathrm{P} 1000 \mathrm{MEA}$ is $350-400 \mu \mathrm{m}$ while the effective water diffusivity through the cathode GDL can be calculated by the Bruggeman expression:

$$
D_{\mathrm{H}_{2} \mathrm{O}}^{e f f}=D_{\mathrm{H}_{2} \mathrm{O}} \varepsilon^{1.5}\left[\mathrm{~m}^{2} \mathrm{~s}^{-1}\right]
$$

$D_{\mathrm{H}_{2} \mathrm{O}}$ is the water diffusivity in air and at $160^{\circ} \mathrm{C}$ it equals $4.77 \times 10^{-5} \mathrm{~m}^{2} \mathrm{~s}^{-1}$ [33] while $\varepsilon$ is the GDL's porosity and it is assumed to be 0.5 . By combining equations (7) and (8) at $160{ }^{\circ} \mathrm{C}$ and with $\delta_{G D L}=400 \mu \mathrm{m}, k_{G D L, c}$ is calculated to be $1.2 \times 10^{-9} \mathrm{~mol} \mathrm{~s}^{-1} \mathrm{~cm}^{-2} \mathrm{~Pa}^{-1}$ which is almost 30 times higher than total water transport coefficient at $160{ }^{\circ} \mathrm{C}$. This means that the resistance through the cathode's GDL accounts for only $\sim 3.5 \%$ of the total MEA resistance. Binary diffusivity of water through hydrogen is calculated to be around five times higher than through air [34], therefore one can conclude that the membrane accounts for more than 95\% of total MEA water transport resistance. The reported data on water transport through PBI membranes in the literature is very scarce and only two articles report water permeability through PBI membrane. In [16] authors estimated the permeability coefficient of water vapor through the PBI/PPy(50)coPSF membrane with a doping level of 6-6.7 at $150{ }^{\circ} \mathrm{C}$ to be $1.1 \times 10^{-14} \mathrm{~mol} \mathrm{~s}^{-1} \mathrm{~cm}^{-1} \mathrm{~Pa}^{-1}$. Another group [29] claims permeability to vary from $4.5 \times 10^{-15}$ to $1.3 \times 10^{-14} \mathrm{~mol} \mathrm{~s}^{-1} \mathrm{~cm}^{-1} \mathrm{~Pa}^{-1}$ for a PBI membrane with a doping level of 5 at $155^{\circ} \mathrm{C}$.

Water vapor permeability of the membrane in this study can be calculated by multiplying the membrane's water transport coefficient by its thickness, which is about 50 $\mu \mathrm{m}:$

$$
P_{m}=\frac{k \delta_{m}}{0.95}\left[\mathrm{~mol} \mathrm{~s}^{-1} \mathrm{~cm}^{-1} \mathrm{~Pa}^{-1}\right]
$$

At $160{ }^{\circ} \mathrm{C} P_{m}$ equals $2.4 \times 10^{-13} \mathrm{~mol} \mathrm{~s}^{-1} \mathrm{~cm}^{-1} \mathrm{~Pa}^{-1}$ which is more than an order of magnitude higher than the values reported in [16] and [29].

\section{Modeling}

\subsection{Mathematical model}

In order to relate the experimentally determined water transport curves to the internal water distribution in a single cell within the stack, a numerical, steady-state 2D model was 
developed. Fig. 7 shows the symmetric 2D modeling domain, which includes straight flow channels, GDLs and the membrane.

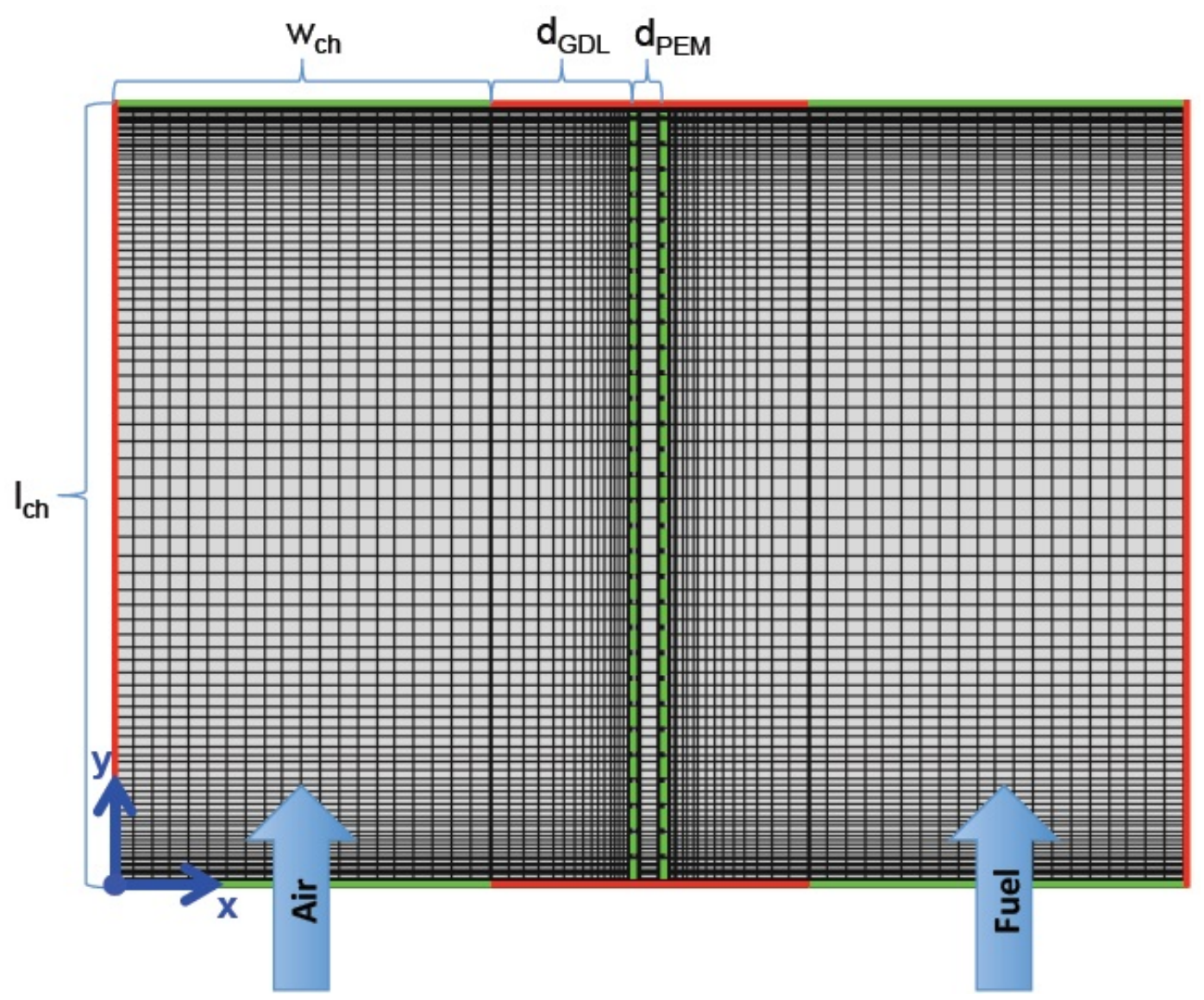

Fig. 7. Modeling domain (aspect ratio not preserved).

The model assumptions are as follows:

- The 2D model cannot capture the real flow field geometry, which is 6-channelserpentine, identical on both anode and cathode. Therefore we assume a straight channel, using the real channel length $l_{c h}=500 \mathrm{~mm}$ from the serpentine geometry and a channel depth of $d_{c h}=10 \mathrm{~mm}$. Hence, the active area of $50 \mathrm{~cm}^{2}$ is maintained.

- Fully developed, laminar flow is assumed in the flow channels.

- The catalyst layers are treated as internal boundaries (dashed green lines in Fig. 7).

- Temperature is assumed to be constant throughout the entire modeling domain.

- Due to the high temperatures $\left(>140^{\circ} \mathrm{C}\right)$ the presence of liquid water is neglected. Water only exists in the vapor phase.

- The EOD is assumed to be negligible, as explained in $[29,30]$. 
The steady-state model equations for conservation of mass, momentum, species and charge $[35,36]$ are presented as follows

$$
\nabla \cdot(\rho \vec{u})=0
$$

$$
\frac{\rho}{\epsilon^{2}}(\vec{u} \cdot \nabla) \vec{u}=-\nabla P+\nabla \cdot(\mu \nabla \vec{u})+S_{u}
$$

$$
\nabla \cdot \vec{\jmath}_{i}+\rho \epsilon(\vec{u} \cdot \nabla) w_{i}=S_{i}
$$

$$
\nabla \cdot\left(\sigma_{S} \nabla \Phi_{S}\right)=S_{S}
$$

$$
\nabla \cdot\left(\sigma_{e} \nabla \Phi_{e}\right)=S_{e}
$$

where $\rho, \vec{u}, P, w_{i}, \Phi_{s}$ and $\Phi_{e}$ denote the fluid density, velocity, total gas pressure, respective mass fraction of the gaseous species $i\left(\mathrm{H}_{2}, \mathrm{O}_{2}, \mathrm{~N}_{2}\right.$ or $\left.\left(\mathrm{H}_{2} \mathrm{O}\right)_{\mathrm{v}}\right)$, electronic phase potential and electrolyte potential. The source terms $S_{u}, S_{i}, S_{s}$ and $S_{e}$ for the respective subdomains are defined in Table 1. All modeling parameters and the associated numerical values are provided in Table 2.

Table 1. Source terms.

\begin{tabular}{|c|c|c|c|}
\hline & $S_{u}$ & $S_{i}$ & $S_{e, s}$ \\
\hline Channels & $S_{u}=0$ & $S_{i}=0$ & $S_{e, s}=0$ \\
\hline GDLs & $S_{u}=-\frac{\mu}{K} \vec{u}$ & $S_{i}=0$ & $S_{e, s}=0$ \\
\hline & & $S_{H_{2}}=-\frac{i}{2 F} M_{H_{2}}$ & \\
ACL & - & $S_{H_{2} O}=D_{H_{2} O}^{P E M} \frac{\left(\left.c_{H_{2} O}\right|_{C C L}-\left.c_{H_{2} O}\right|_{A C L}\right)}{d_{P E M}} M_{H_{2} O}$ & $S_{e}=i_{a}$ \\
& & $S_{O_{2}}=-\frac{i}{4 F} M_{O_{2}}$ & \\
CCL & - & $S_{H_{2} O}=-D_{H_{2} O}^{P E M} \frac{\left(\left.c_{H_{2} O}\right|_{C C L}-\left.c_{H_{2} O}\right|_{A C L}\right)}{d_{P E M}} M_{H_{2} O}$ & $S_{s}=-i_{c}$ \\
& & $+\frac{i}{2 F} M_{H_{2} O}$ & \\
\hline
\end{tabular}


Table 2. Physical properties and constants.

\begin{tabular}{|c|c|c|}
\hline Parameter & Value & Unit \\
\hline Geometry & & \\
\hline Channel length, $l_{c h}$ & 500 & $\mathrm{~mm}$ \\
\hline Channel width, $w_{c h}$ & 1 & $\mathrm{~mm}$ \\
\hline Channel depth, $d_{c h}$ & 10 & $\mathrm{~mm}$ \\
\hline GDL thickness, $d_{G D L}$ & 0.4 & $\mathrm{~mm}$ \\
\hline PEM thickness, $d_{P E M}$ & 0.05 & $\mathrm{~mm}$ \\
\hline Active area, $A_{a c t}$ & 50 & $\mathrm{~cm}^{2}$ \\
\hline Electrochemical parameters & & \\
\hline Equilibrium potential, $E_{0}$ & 1.0 & $\mathrm{~V}$ \\
\hline Anode exchange current density, $i_{0, a}$ & 1 & $\mathrm{~A} \mathrm{~cm}^{-2}$ \\
\hline Cathode exchange current density, $i_{0, c}$ & $3.5 e-5$ & $\mathrm{~A} \mathrm{~cm}^{-2}$ \\
\hline Cathode Charge transfer coefficient, $\alpha_{c}$ & 0.7 & - \\
\hline Temperature, $T$ & 160 & ${ }^{\circ} \mathrm{C}$ \\
\hline Material properties & & \\
\hline Electrolyte conductivity, $\sigma_{e}$ & 2.4 & $\mathrm{~S} \mathrm{~m}^{-1}$ \\
\hline GDL through-plane conductivity, $\sigma_{s, x x}$ & 1250 & $\mathrm{~S} \mathrm{~m}^{-1}$ \\
\hline GDL in-plane conductivity, $\sigma_{s, y y}$ & 17860 & $\mathrm{~S} \mathrm{~m}^{-1}$ \\
\hline GDL porosity, $\epsilon_{G D L}$ & 0.5 & - \\
\hline GDL Permeability, $K_{G D L}$ & $1 \mathrm{e}-12$ & $\mathrm{~m}^{2}$ \\
\hline Channel porosity, $\epsilon_{c h}$ & 1 & - \\
\hline Cathode gas viscosity, $\mu_{c}$ & $2.46 \mathrm{e}-5$ & $\mathrm{~Pa} \mathrm{~s}$ \\
\hline Anode gas viscosity, $\mu_{a}$ & $8.76 \mathrm{e}-6$ & $\mathrm{~Pa} \mathrm{~s}$ \\
\hline Binary diffusion coefficient $@ \mathrm{~T}=160^{\circ} \mathrm{C}, D_{H 2, H 2 O}$ & $3.05 \mathrm{e}-4$ & $\mathrm{~m}^{2} \mathrm{~s}^{-1}$ \\
\hline Binary diffusion coefficient $@ \mathrm{~T}=160^{\circ} \mathrm{C}, D_{N 2, H 2 O}$ & $6.26 \mathrm{e}-5$ & $\mathrm{~m}^{2} \mathrm{~s}^{-1}$ \\
\hline Binary diffusion coefficient $@ \mathrm{~T}=160^{\circ} \mathrm{C}, D_{O 2, H 2 O}$ & $5.98 \mathrm{e}-5$ & $\mathrm{~m}^{2} \mathrm{~s}^{-1}$ \\
\hline Binary diffusion coefficient $@ \mathrm{~T}=160^{\circ} \mathrm{C}, D_{O 2, N 2}$ & $4.06 \mathrm{e}-5$ & $\mathrm{~m}^{2} \mathrm{~s}^{-1}$ \\
\hline
\end{tabular}

The two-dimensional water transport analysis in this work is based on the water transport model for low temperature PEM fuel cells, presented by Strahl et al. [32]. Momentum transport (Eq. (11)) in the flow channels is described by the Navier-Stokes equation. The source term $S_{u}$ accounts for the pressure gradient in the GDL following Darcy's law. The conservation of gaseous species (Eq. (12)) includes multi-component diffusion and convection. The diffusive mass flux $\vec{J}_{i}$ is based on multi-component gas diffusion, which is approximated by the Maxwell-Stefan equation to account for the gradient in the mole fractions of the gas components. A Bruggeman correction with a tortuosity of 1.5 is used to calculate the effective binary diffusivities in the porous diffusion media. The source terms $S_{i}$ on the catalyst layer boundaries describe reactant consumption and water generation based on the electrochemical reactions. The transport of water vapor through the membrane is described by Fick's law of diffusion, in which the experimentally determined water diffusion 
coefficient is used. Since the membrane itself is not modeled, the respective sink/source terms for the water vapor transport through the membrane are applied to the anode and cathode catalyst layers.

The experimentally validated reaction kinetics described by a Butler-Volmer approach defines the source terms in the charge conservation equations (Eqs. (13) and (14)). The overpotential at the catalyst surface is defined as:

$$
\eta=\Phi_{s}-\Phi_{e}-E_{0}
$$

where $E_{0}$ is the equilibrium potential, which is the thermodynamic reversible potential under the given operating temperature and pressure minus crossover losses.

The current densities at the anode and cathode catalyst boundary are described by equations (16) and (17), respectively. Since the hydrogen oxidation reaction kinetics is fast compared to the oxygen reduction reaction kinetics, the anode reaction kinetics is described by a concentration dependent, linearized Butler-Volmer approach [34]. A concentration dependent cathodic Tafel equation describes the cathode reaction kinetics.

$$
i_{a}=i_{0, a} \cdot\left(\frac{c_{H 2}}{c_{H 2, r e f}}\right)^{0.5} \cdot\left(\frac{\alpha_{a} F}{R T} \eta\right)
$$

$$
i_{c}=i_{0, c} \cdot\left(\frac{c_{O 2}}{c_{O 2, \text { ref }}}\right)^{2} \cdot \exp \left(-\frac{\alpha_{c} F}{R T} \eta\right)
$$

On the right hand side of equations (16) and (17) $i_{0, x}$ represents the exchange current density, $c_{x}$ is the local concentration of reactants at the catalyst surface and $c_{x, \text { ref }}$ is the reference concentration at the respective pressure and temperature. The relation between anodic and cathodic charge transfer coefficient is described by equation (18).

$$
1=\alpha_{c}+\alpha_{a}
$$

\section{Boundary conditions}

The boundary conditions for the electrochemical model are a fixed potential at the cathode channel/GDL interface of $\Phi_{S}=V_{\text {cell }}$ and electrical ground at the anode channel/GDL interface with $\Phi_{S}=0$. Concerning the gas phase transport, an ideal membrane is assumed which is impermeable to reactant gases. The reactant mass fractions at the channel inlets are constant, with $w_{O 2}=0.23$ and $w_{H 2}=0.9999$ for the dry case. For the humidified anode the inlet mass fraction of water vapor was set to $w_{H 2 O v, a}=0.31$ and 0.49 for a dew point of $33^{\circ} \mathrm{C}$ and $45^{\circ} \mathrm{C}$, respectively.

The stoichiometry dependent inlet gas velocities for the anode and cathode channels are as follows: 


$$
u_{a, i n}=\lambda_{a} \frac{i R T A_{a c t}}{2 F p^{H 2} A_{i n}}
$$

$$
u_{c, \text { in }}=\lambda_{c} \frac{i R T A_{a c t}}{4 F p^{O 2} A_{\text {in }}}
$$

where $i$ is the average current density at the catalyst surface, calculated from the integral of the local current density:

$$
i=\frac{1}{A_{\text {act }}} \int_{A_{\text {act }}} i_{\text {loc }} d A
$$

The cross sectional inlet area of the flow channels $A_{\text {in }}$ in equations (19) and (20) is defined as the product of channel width $w_{c h}$ with the channel depth $d_{c h} . \quad \lambda_{a}, \lambda_{c}, p^{H 2}$ and $p^{O 2}$ are the anode stoichiometry, cathode stoichiometry, partial pressure of hydrogen and partial pressure of oxygen at the channel inlets, respectively.

At the channel outlets a constant pressure of 1 atm is set, assuming fully developed laminar flow. A no-flux condition applies to all other external boundaries (red lines in Fig. 7).

\section{Numerical implementation}

The mathematical 2D model was implemented and solved in COMSOL Multiphysics ${ }^{\circledR}$ according to the modeling domain, shown in Fig. 7. The 2D mesh consists of 12350 quadrilateral elements and is refined towards the CLs and the channel inlets and outlets. The solution of the stand-alone electrochemical model is used as initial value for solving the entire equation system. Convergence is reached within 10 iterations under a relative tolerance of $10^{-4}$.

\subsection{Validation and discussion of simulation results}

\section{Experimental validation}

The model was experimentally validated with the fuel cell stack under study. The electrolyte conductivity was determined experimentally by electrochemical impedance spectroscopy (ohmic resistance). The electrochemical parameters $i_{0, c}$ and $\alpha_{c}$ were determined by fitting the polarization curve. The initial values for $i_{0, c}$ and $\alpha_{c}\left(5 \times 10^{-5} \mathrm{~A} \mathrm{~cm}^{-2}\right.$ and 0.7 , respectively) were taken from [37]. In order to fit the experimental data $\alpha_{c}$ was kept constant and $i_{0, c}$ was decreased stepwise with a step width of $0.5 \times 10^{-5} \mathrm{~A} \mathrm{~cm}^{-2}$. Fig. 8 shows the comparison of the experimental polarization curves with the simulation at different stoichiometries. The model predicts the average current density as a function of the cell potential very well. The effect of the cathode stoichiometry on cell performance is captured 
properly. The data of the two humidified scenarios are not shown in Fig. 8 for the sake of clarity and because no effect on fuel cell performance could be observed. The experimental polarization curves with anode humidification at a dew point of 33 and $45{ }^{\circ} \mathrm{C}$ are identical to the dry case at the respective cathode stoichiometry.

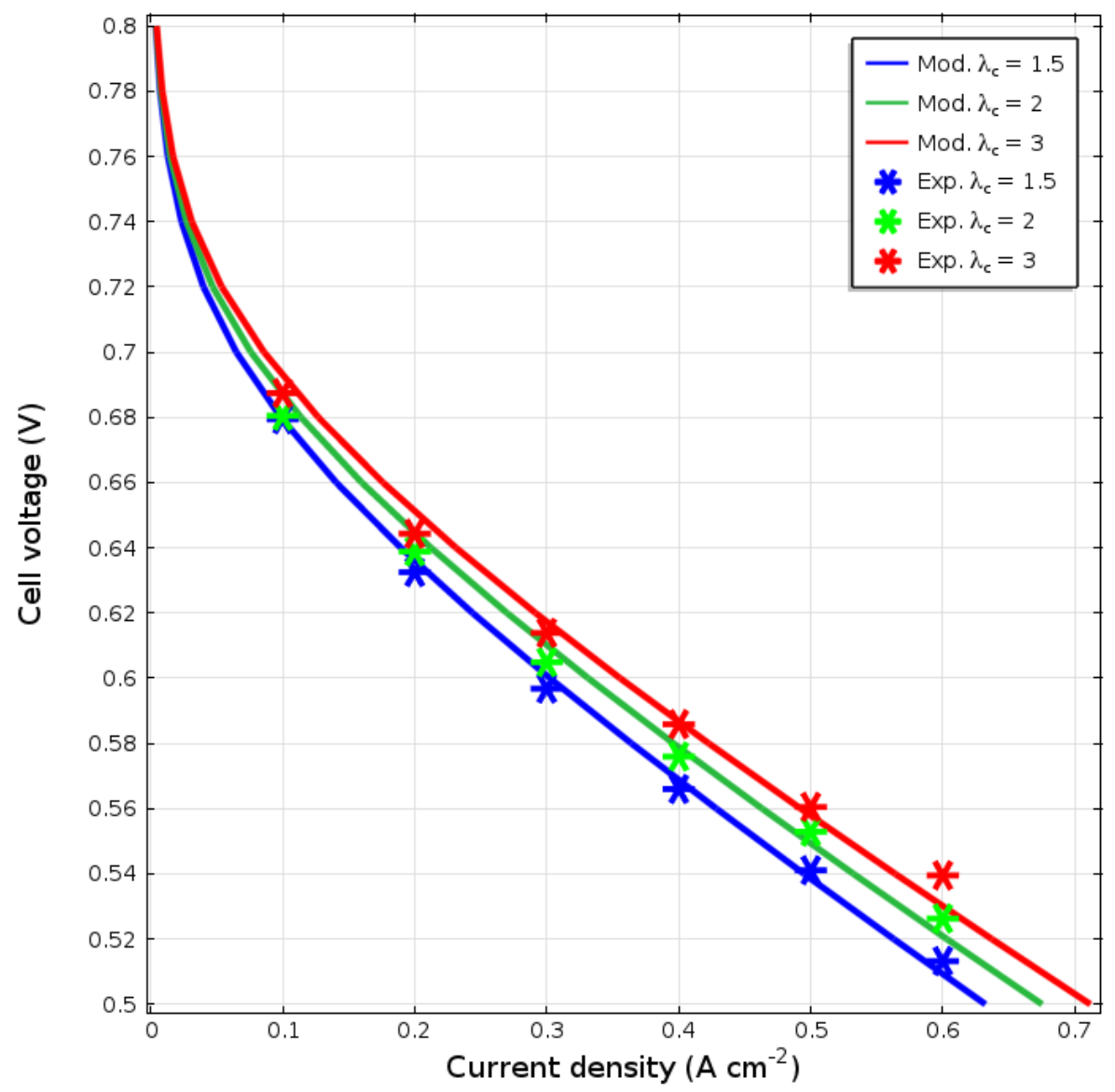

Fig. 8. Experimental and modeled polarization curves at different cathode stoichiometries.

Fig. 9 compares the experimental data with the model for the fitted water diffusivity coefficient through the membrane, $D_{H 2 O}^{P E M}$ (conservation of species, Table 2). The water permeability coefficient is then easily calculated from the obtained diffusivity coefficient by

$$
P_{m}=\frac{D_{H 2 O}^{P E M}}{R T}
$$

where, $R$ and $T$ are universal gas constant and cell temperature. Calculations show that for the best fitted diffusivity coefficient, the obtained permeability coefficient is four times higher than the one obtained experimentally. The experimentally determined water transport coefficient was obtained in a "non-operating" mode with finite water partial pressure differences at each side of the MEA and nitrogen, similarly to the procedures for obtaining water transport (or permeability) coefficients in LTPEM fuel cells as well as in HTPEM fuel cells presented in $[16,29,31]$. Under fuel cell operation the water content in the membrane may be significantly higher than without operation, which could increase the water diffusivity 
similar as in LTPEM fuel cells. As shown in the previous section, there is an indication that membrane permeability rises with an increase of relative humidity, but this is yet to be investigated. Also, authors in [29] claim that water permeability coefficient can vary up to a factor of 3, however, they do not specify under what conditions.

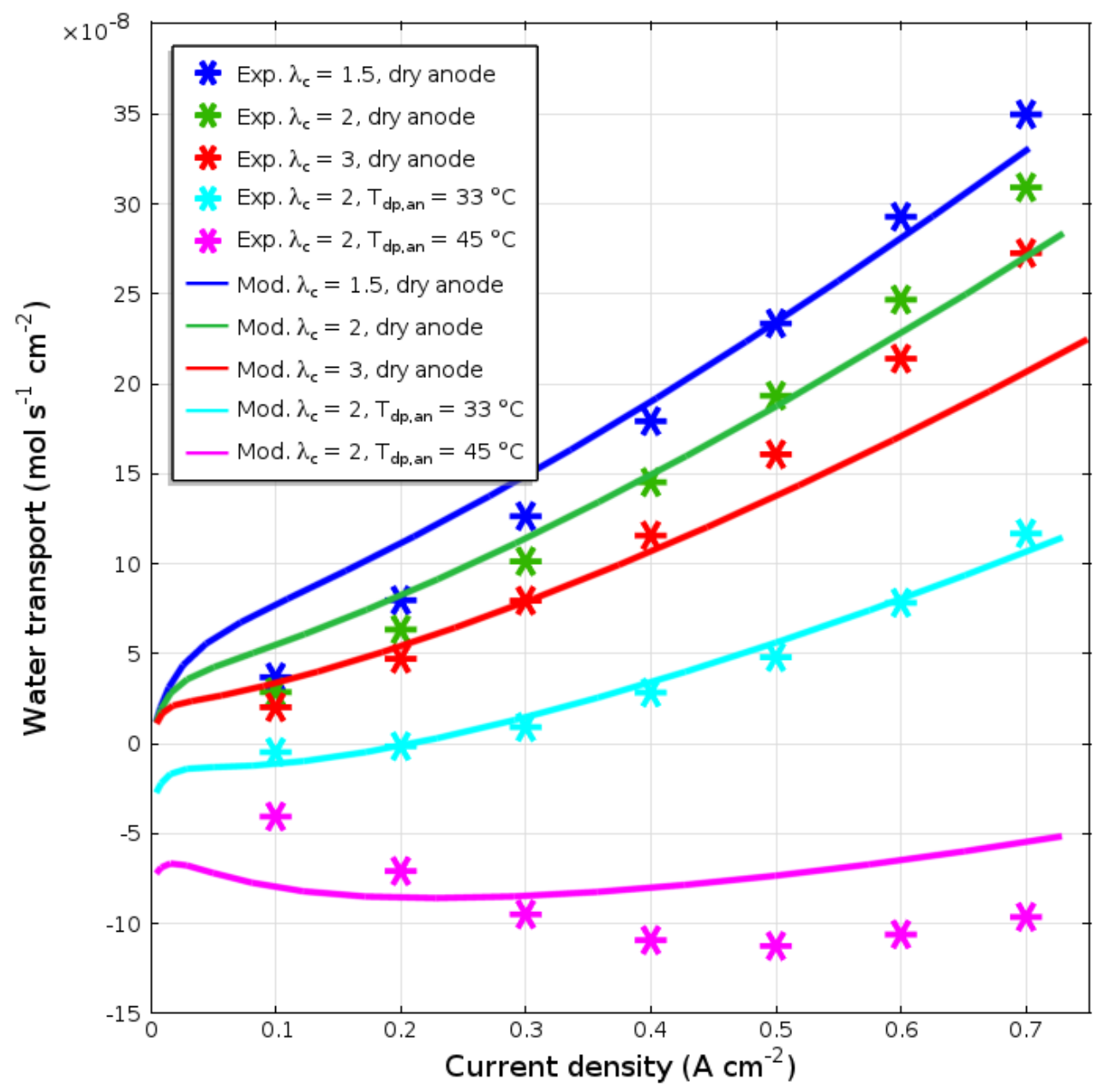

Fig. 9. Comparison of experimental and simulation results for the water transport.

To compare the simulation results with the experimental data, the modeled local water transport along the channel was averaged over the active area:

$$
\dot{Q}_{c \rightarrow a}^{H_{2} \mathrm{O}}=\frac{1}{A_{a c t}} \int_{A_{\text {act }}} \dot{Q}_{\text {loc }}^{\mathrm{H}_{2} \mathrm{O}} d A
$$

The calculated water transport generally follows the same trend as the experimental however the model tends to overestimate it at lower current densities and underestimate it at higher current densities. There are several possible reasons for this behavior. First, the EOD which is generally considered to be negligible $[29,30]$ still can be present at a lower scale, especially for membranes with higher doping levels and consequently higher amounts of free mobile ions such is the case with Celtec ${ }^{\mathbb{R}}-\mathrm{P} 1000$ membranes. Second, the membrane permeability 
coefficient may be somewhat different from the one calculated, as explained above, or it may not even be constant along the channel length.

\section{Local water transport distribution along the channel}

Fig. 10 shows the water vapor concentration in anode and cathode GDL and channel at an operating point of $0.5 \mathrm{~V}$, dry reactant gases and a cathode stoichiometry of 3 . Water vapor concentration is increasing along the channel on both sides of the membrane. Since there is a two orders of magnitude difference between $\mathrm{x}$ and $\mathrm{y}$ dimensions of the modeled cell, the aspect ratio in the plot of the entire cell is not preserved, which results in almost horizontal contour lines. However, the real water vapor profile in the $\mathrm{x}$-direction with a preserved aspect ratio is shown in the magnified snapshots on the left side of Fig. 10 at two locations along the channel length. It can be seen that the local water transport through the membrane changes its direction since cathode water concentration is higher than anode water concentration at $\mathrm{y}=$ $210 \mathrm{~mm}$ whereas vice versa at $\mathrm{y}=445 \mathrm{~mm}$.

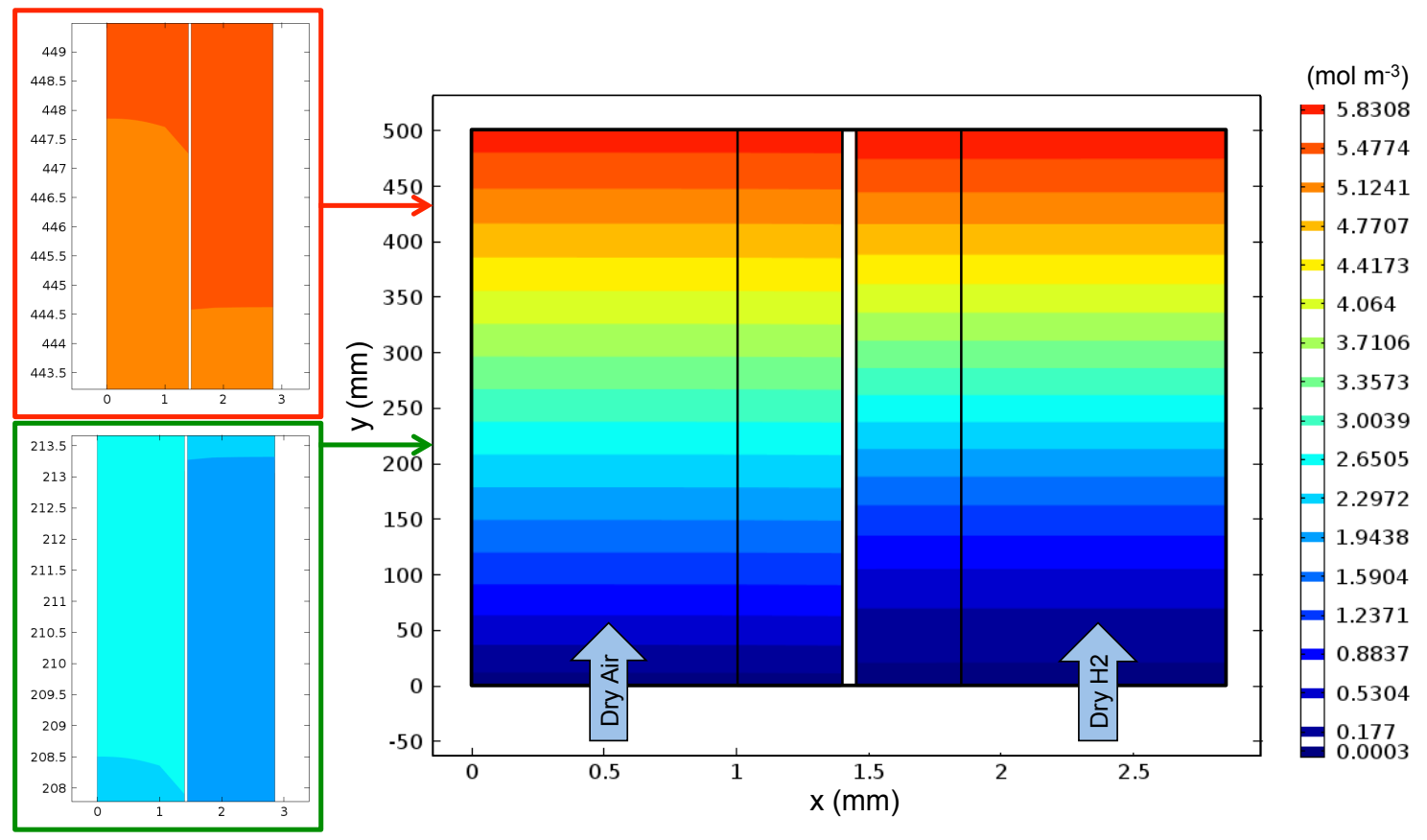

Fig. 10. Water vapor concentration in the GDL and flow channel of both cathode and anode at a cell voltage of $0.5 \mathrm{~V}$, dry reactants, a cathode stoichiometry of 3 and an anode stoichiometry of 1.3 .

Fig. 11(a) shows the local water transport profiles along the flow channel for a dry anode inlet at the three tested cathode stoichiometries and two chosen cell voltages. As it can be seen, the model confirms the experimental findings that the water vapor transport along the channel changes its direction from initially cathode to anode to the opposite direction towards the end of the channel. The higher water production rate at the lower cell potential of $0.5 \mathrm{~V}$ results in a sharper gradient of water transport and shifts the peak water transport deeper into the channel, which leads to a faster water vapor accumulation in the anode gas stream. Thus, even at the higher stoichiometry of 2 the anode outlet water vapor concentration is still higher than at the cathode, unlike at a cell potential of $0.6 \mathrm{~V}$, where less water is available in the 
system. If and where the local water transport crosses zero depends on the operating current and the cathode stoichiometry. Proper cathode stoichiometry control may be used to manipulate the location and height of the water transport peak and the zero crossing point.

The effect of anode humidification at an inlet dew point of $33{ }^{\circ} \mathrm{C}$ and a fixed cathode stoichiometry of 2 is shown in Fig. 11(b). Water transport at the inlet is negative since the cathode is supplied with dry air. However, water production at the cathode dominates the water transport along the channel and therefore the local water transport distribution for the humidified anode approximates the dry anode distribution towards the end of the channel. This may include two changes of the water transport direction, as shown for a cell voltage of $0.5 \mathrm{~V}$. The results for anode humidification at an inlet dew point of $45^{\circ} \mathrm{C}$ are similar and are not shown in Fig. 11(b) for the sake of clarity.

a)

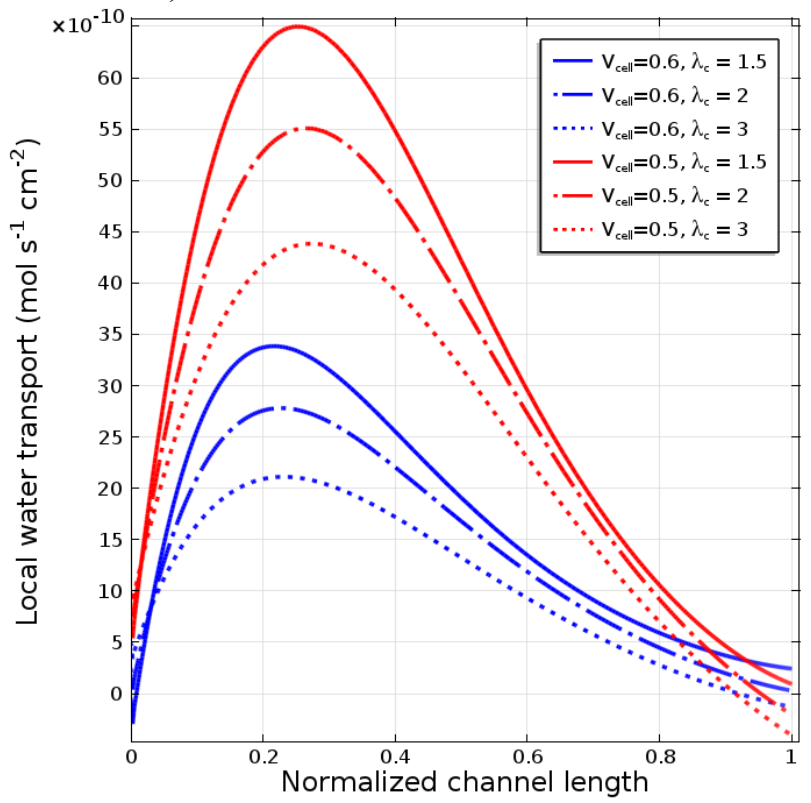

b)

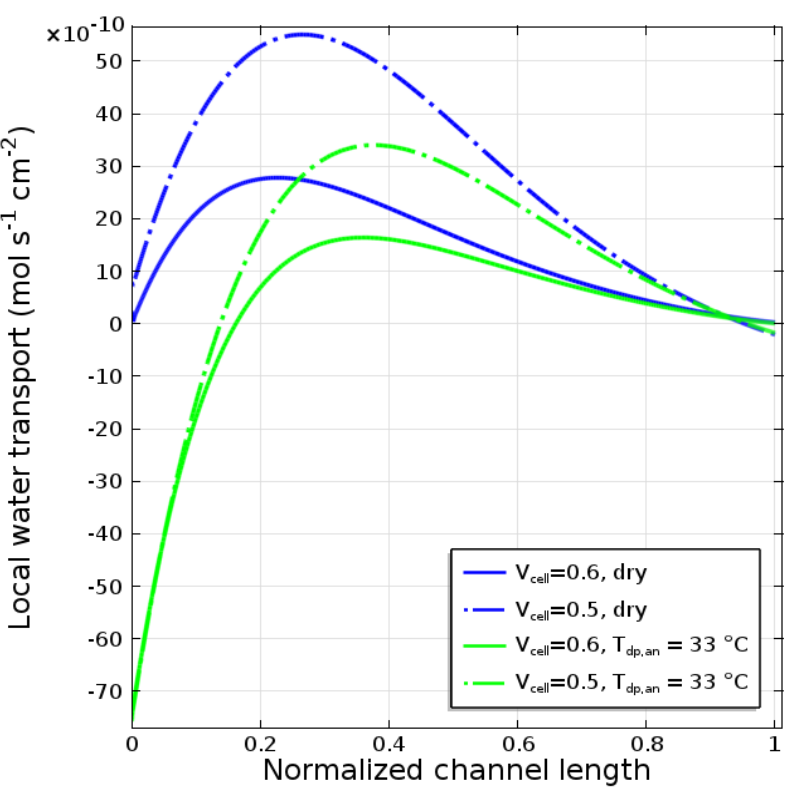

Fig. 11. Comparison of simulated local water transport along the flow channel at different cell voltages, (a) different cathode stoichiometries and (b) with anode humidification.

Fig. 12(a) shows the profiles of hydrogen mole fraction along the flow channel for a dry anode inlet at different cathode stoichiometries and cell potentials. Water transport from cathode to anode leads to a decreasing hydrogen concentration towards the end of the channels, especially at lower cathode stoichiometry. This is even worse at anode stoichiometries less than the 1.3 used in this work. The results with a humidified anode and a fixed cathode stoichiometry of 2 are compared to the dry case in Fig. 12(b). It is shown how additional water in the anode dilutes hydrogen and results in overall lower hydrogen mole fractions along the channel. For instance, anode humidification at a dew point of only $45^{\circ} \mathrm{C}$ and a cell voltage of $0.6 \mathrm{~V}$ reaches the same outlet hydrogen mole fraction as the dry anode configuration at $0.5 \mathrm{~V}$. This may become a serious performance problem when operating on reformed hydrogen, where the inlet mole fraction of hydrogen is much lower than 1. 
a)

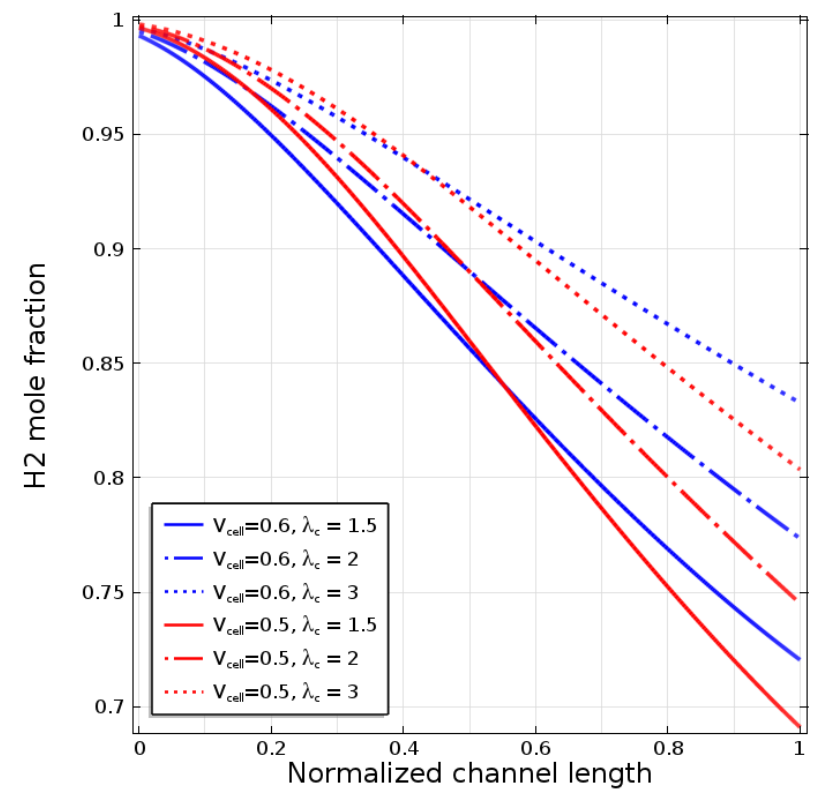

b)

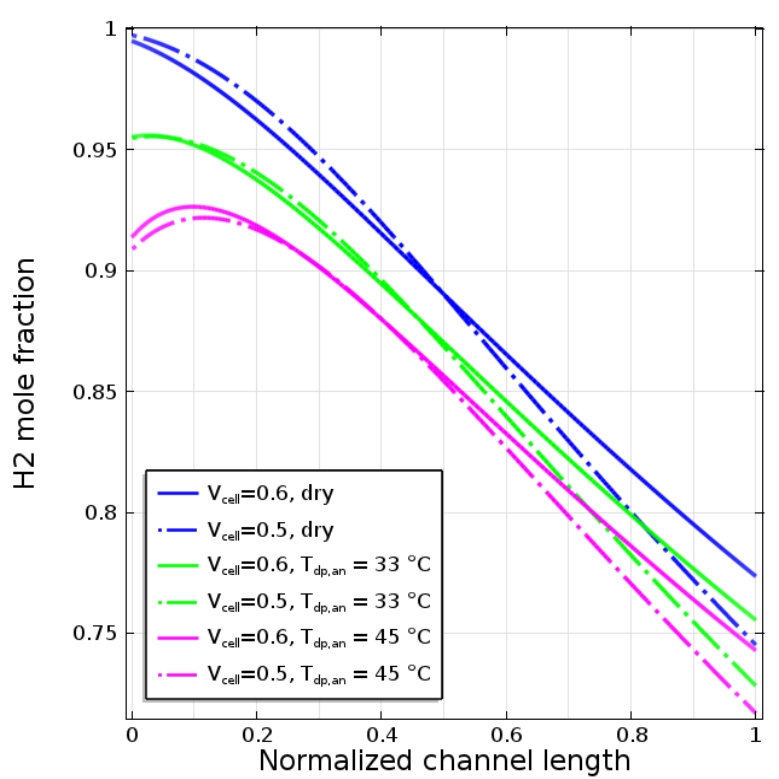

Fig. 12. Comparison of simulated hydrogen mole fraction at the anode catalyst layer along the flow channel at different cell voltages, (a) different cathode stoichiometries and (b) with anode humidification.

\section{Conclusions}

HTPEM fuel cells do not need humidified reactants to operate. However, in real world applications reactants are unlikely to be completely dry. Several reports have shown that water vapor can have an influence on the fuel cell performance, both positive and negative. Therefore, water vapor transport across the MEA during cell operation has been quantified and it has been shown that a considerable amount of water can cross the MEA. Water transport from cathode to the anode rises with current density and drops with cathode stoichiometry. Moreover, water vapor partial pressure at the anode outlet almost always exceeds the cathode outlet water vapor partial pressure even when using dry reactants. This means that at some point along the channel water transport changes direction (diffusion now from anode to cathode instead of cathode to anode). This information is important for the design of HTPEM fuel cells and their control. For instance, at low stoichiometry or a deadended anode the water concentration at the anode outlet can get quite high, which in turn lowers the concentration of hydrogen. It has been shown in this work that water and hydrogen concentration can be controlled the by the cathode flow rate. This may be even more critical when operating with reformed gases where the hydrogen concentration is already low.

To study the effects of flow rate on the concentration of the reactant gases along the flow channels, a 2D model was developed and was validated against the experimental findings. The model fits the experimental data reasonably well; however it tends to overestimate the water transport at lower and underestimate it at higher current densities. In future work, the 
model may be used to investigate counterflow or dead-ended anode operation effects on water transport in combination with different reactant compositions, e.g. with reformed hydrogen.

The membrane's water permeability coefficient was experimentally determined to be $2.4 \times 10^{-13} \mathrm{~mol} \mathrm{~s}^{-1} \mathrm{~cm}^{-1} \mathrm{~Pa}^{-1}$ at $160{ }^{\circ} \mathrm{C}$ which is more than an order of magnitude higher than previously reported values. The modeling results propose that the water transport coefficient might be higher than the one obtained experimentally. This also supports the assumption that the permeability coefficient might be dependent on relative humidity and it could be somewhat higher than the value reported here, but further investigation is needed.

\section{Acknowledgments}

All the experimental tests were performed at the Fuel Cell Laboratory of the Institut de Robotica i Informatica Industrial (CSIC-UPC, Barcelona). This work is partially funded by the project of CICYT DPI2011-25649 MICINN. Finally, the authors highly appreciate the support of the Institut de Robotica i Informatica Industrial in enabling a research stay of Dario Bezmalinović at the Fuel Cell Laboratory in Barcelona.

\section{References}

[1] Jianlu Zhang, Z. Xie, Jiujun Zhang, Y. Tang, C. Song, T. Navessin, Z. Shi, D. Song, H. Wang, D.P. Wilkinson, Z.S. Liu, S. Holdcroft, Journal of Power Sources, 160 (2006) 872-891.

[2] Q. Li, J.O. Jensen, R.F. Savinell, N.J. Bjerrum, Progress in Polymer Science, 34 (2009) 449-477.

[3] A. Arsalis, M.P. Nielsen, S.K. Kaer, International Journal of Hydrogen Energy, 36 (2011) 5010-5020.

[4] G.C. Bandlamudi, M. Saborni, P. Beckhaus, F. Mahlendorf, A. Heinzel, Journal of Fuel Cell Science and Technology, 7 (2010) 0145011-0145012.

[5] Q. Li, R. He, J.O. Jensen, N.J. Bjerrum, Fuel Cells 4 (2004) No. 3, 147-159.

[6] Jianlu Zhang, Y. Tang, C. Song, Jiujun Zhang, Journal of Power Sources, 172 (2007) $163-171$.

[7] N. Jalani, M. Ramani, K. Ohlsson, S. Buelte, G. Pacifico, R. Pollard, R. Staudt, R. Datta, Journal of Power Sources, 160 (2006) 1096-1103.

[8] S. Galbiati, A. Baricci, A. Casalegno, R. Marchesi, International Journal of Hydrogen Energy, 37 (2012) 2462-2469.

[9] Y. Oono, T. Fukuda, A. Sounai, M. Hori, Journal of Power Sources, 195 (2010) 10071014. 
[10] Q. Li, R. He, J. Gao, J. O. Jensen, N. J. Bjerrum, Journal of Electrochemical Society (150) 2003 A1599-A1605.

[11] T.J. Schmidt, J.Baurmeister, ECS Transactions, 3(1)(2006) 861-869.

[12] Y. Zhai, H. Zhang, D. Xing, Z.G. Shao, Journal of Power Sources, 164 (2007) 126133.

[13] Z. Qi, S. Buelte, Journal of Power Sources, 161 (2006) 1126-1132.

[14] T.J. Schmidt, J. Baurmeister, Journal of Power Sources, 176 (2008) 428-434.

[15] Y. Choi, H.G. Stenger, Journal of Power Sources, 124 (2003) 432-439.

[16] M.K. Daletou, J.K Kallitsis, G. Voyiatzis, S.G. Neophytides, Journal of Membrane Science 326 (2009) 76-83.

[17] Z. Liu, J.S. Wainright, M.H. Litt, R.F. Savinell, Electrochimica Acta, 51 (2006) 3914-3923.

[18] Y.L. Ma, J.S. Wainright, M.H. Litt, R.F. Savinell, Journal of Electrochemical Society, 151 (2004) A8-A16.

[19] A.Schechter, R.F Savinell, J.S. Wainright, D. Ray, Journal of Electrochemical Society, 156 (2) (2009) B283-B280.

[20] J. Lobato, P. Cañizares, M.A. Rodrigo, J.J. Linares, Electrochimica Acta, 52 (2007) 3910-3920.

[21] M. Mamlouk, K. Scott, International Journal of Energy Research, 35 (2011) 507-519.

[22] K. Wippermann, C.Wannek, H.-F. Oetjen, J. Mergel, W. Lehnert, Journal of Power Sources, 195 (2010) 2806-2809.

[23] J.J. Linares, C. Sanches, V.A. Paganin, E.R. Gonzalez, International Journal of Hydrogen Energy 37 (2012) 7212-7220.

[24] M. Bonaventura, A. Mendes, International Journal of Hydrogen Energy, 35 (2010) 11649-11660.

[25] C. Y. Chen, W.H. Lai, Journal of Power Sources, 195 (2010) 7152-7159.

[26] R. He, Q. Li, G. Xiao, N.J. Bjerrum, Journal of Membrane Science, 226 (2003) 169184.

[27] Users Manual, High Temperature Fuel Cell (HT-PEMFC) Stack (12 Cells), ZBT, 2012.

[28] Celtec ${ }^{\circledR}-\mathrm{P} 1000$ Membrane Electrode Assembly, Technical Information Brochure, BASF, June 2007. 
[29] D. Weng, J.S. Wainright, U. Landau, R.F. Savinell, Journal of Electrochemical Society 143 (1996) 1260-1263.

[30] Q. Li, H.A Hjuler, N.J. Bjerrum, Journal of Applied Electrochemistry 31 (2001) 773779.

[31] A. Husar, A. Higier, H. Liu, Journal of Power Sources 183 (2008) 240-246.

[32] S. Strahl, A. Husar and M. Serra, Journal of Power Sources, 196(9), (2011) 42514263.

[33] http://www.cambridge.org/us/engineering/author/nellisandklein/downloads/extended /chapter\%209.pdf

[34] R. O’Hayre, S.W. Cha, W. Colella, F.B. Prinz, Fuel cell fundamentals, Wiley, 2009.

[35] F. Barbir, PEM Fuel Cells: Theory and Practice, Elsevier Academic Press, 2005.

[36] U. Pasaogullari, C. Y. Wang, Journal of The Electrochemical Society, 152(2) (2005) A380-A390.

[37] M. Kvesić, U. Reimer, D. Froning, L. Lüke, W. Lehnert, D. Stolten, International Journal of Hydrogen Energy, 37 (17) (2012) 12438-12450. 